In these surroundings Cullen found scope for his wider interests and inherent sympathies. The admirable spirit of co-operation, and the refreshing freedom from secrecy regarding experience and knowledge of technical matters, which he found to exist among those directing the mining industry were fully in accord with an outlook which may be regarded as one of his happiest characteristics. Two matters in particular caused him grave concern. First, the appalling mortality, at that time, among those engaged in underground mining, and secondly, the widespread neglect to provide technical training for the younger members of the community. To both these problems Cullen gave unremitting thought and attention, which persisted, in one form or an. other, to the end of his life.

As the direct outcome of his own responsibilities, Cullen sought for more precise information regarding the nature of the gases resulting from the explosives which, at that time, were in general use underground. The previous neglect of this aspect of blasting operations was attributed by Cullen to a lack of contact between the manufacturers and the users of explosives, but "there," he said in one of his addresses, "we lived next door to each other." The results of the investigations, with relatively crude appliances and despite the serious hazards which close sampling involved, shocked them all. Ready, as he always was, to face up to unpalatable facts, he pursued these investigations in collaboration with his colleagues, T. Donaldson, E. Weiskopf and W. Waters. Discussions, following the publication of their results, lasted many months. Public conscience was aroused, and the Government took note. A commission was appointed (at which Cullen was an important witness) and the matter was followed by further work.

Although these inquiries did not attempt to go to the root causes of silicosis, as subsequent work has done, they, nevertheless, did much towards eliminating the hazards of poisoning from carbon monoxide and the oxides of nitrogen by establishing on a firm basis the need of an 'oxygen balance' in regard to all explosives used underground. Cognizance of this important requirement was taken all over the world. At the same time, Cullen was not unmindful of the unsolved problems of ventilation in mines; and the stimulus thus given to the need for greater attention to this matter has helped towards the immense advances which have now been made in this direction.

In regard to education and training, both in South Africa and in Great Britain, Cullen lived to see many of his cherished hopes and aspirations realized. As a member of the original Transvaal Council of Education and as an active participant in the work of the Transvaal Technical Institute, he helped to pave the way for the foundation of the University of the Witwatersrand. Recognition of these services was made in 1925, when the University conferred upon him the honorary degree of LL.D. He continued to represent the interests of the University in Great Britain. Of many ways in which he sought to promote its welfare, perhaps the outstanding service was the part he played, under the chairmanship of the Earl of Athlone, in making good, so far as possible, the losses sustained by the Library of the University as the result of the disastrous fire on Christmas Eve of 1931.

In addition to his unremitting services on the councils of those institutions and technical bodies over which he had in turn presided and of which he was later elected to honorary membership, he was an indefatigable lecturer and speaker on matters which came within his wide experience. As recently as 1944 he was called upon to preside over the deliberations of the Science Masters' Association.

Such were the activities of a man of far-seeing vision and buoyant disposition with a unique experience of men and affairs, one who has left a mark on generations of chemical technologists, mining engineers and metallurgists, and one to whom they could look with confidence at all times for guidance, encouragement and enduring friendship.

$$
\text { S. W. Sмттн }
$$

\section{Sir Thomas Crozier}

Major Sir Thomas Henry Crozier, formerly His Majesty's Chief Inspector of Explosives at the Home Office, died at Folkestone on September 26 at the age of eighty. Born at Monkstown, County Dublin, on February 26, 1868, he was educated at the United Services College, Westward Ho, and the Royal Military Academy, Woolwich, and was gazetted to the Royal Artillery in 1888. He held the posts of chief instructor in ammunition and explosives at the Ordnance College and afterwards chief instructor in artillery at the Royal Military Academy. He retired from the Army on April 17, 1908, when he was appointed one of His Majesty's inspectors of explosives at the Home Office.

On October 5, 1914, he rejoined the Army and served in "A" Battery of the 58th Brigade, Royal Field Artillery, 11th Division, Mediterranean Expeditionary Force. He was eventually invalided, and on recovery and after urgent representations by the Home Office owing to the greatly increased pressure of work, he rejoined the Explosives Department of the Home Office in October 1915. On February 12, 1926, he was appointed His Majesty's chief inspector of explosives. His work was rewarded on June 3, 1930, by the conferment of a knighthood. He retired on March 30, 1931.

During Sir Thomas's term of office in the Explosives Department, low-freezing explosives were introduced into general use in Great Britain, and the Petroleum Act, 1926, and the Petroleum (Consolida. tion) Act, 1928, were passed. Regulations were made for the conveyance by road of petroleum spirit, carbon disulphide and for the 'permanent' gases compressed in a metal cylinder. He was associated with a number of committees dealing with petroleum, dissolved acetylene, fire extinguishers, permitted explosives, classification of explosives used by the Fighting Services, carriage of dangerous goods in ships, welded containers, and cylinders for permanent and liquefiable gases. During the years 1927 and 1928 , in conjunction with the late Prof. J. S. S. Brame, he carried out, on behalf of the Minister of Transport, a public inquiry into the modifications of the petroleum spirit by-laws proposed to be made by the Port of London Authority.

During the Second World War, the work of the Explosives Department increased considerably and, in consequence, Sir Thomas Crozier was asked to rejoin the Department, which he did on June 1, 1940. He relinquished this temporary appointment on September 30, 1944, owing to ill-health. 